\title{
Berenika Drazewska*
}

berenika.drazewska@eui.eu

International Law of Culture Interest Group

European Society of International Law

Independent scholar

Singapore

\section{Hasankeyf, the llisu Dam, and the Existence of "Common European Standards" on Cultural Heritage Protection}

\begin{abstract}
The struggle to save Hasankeyf from the now imminent flooding in connection with the construction of the hydroelectric dam at Ilisu on the Tigris river in the southeastern part of Turkey has been the subject of international attention for decades. The first part of this paper describes the process with respect to the financing and construction of the dam, examining in particular the lessons learned as to the role of international standards on the protection of cultural heritage in development and their implementation through different actors and processes. The second part discusses the case against Turkey brought by Turkish citizens before the European Court of Human Rights in connection with the construction of the Ilisu dam, highlighting that - despite the outcome of the case - it might still be considered a step forward toward advancing public interest liti-
\end{abstract}

\footnotetext{
* Berenika Drazewska holds an LL.M. and a Ph.D. in international cultural heritage law from the European University Institute (2016). In her doctoral thesis she examined the concept of military necessity in the context of protection of cultural heritage during armed conflicts. At the EUI, she was one of the coordinators of the Cultural Heritage Working Group which organized conferences, workshops, and seminars on legal issues relevant to cultural heritage protection. In 2012, Berenika interned in the International Treaties section of UNESCO in Paris. In 2016/2017, she was a Postdoctoral Fellow at the Faculty of Law, Tel Aviv University, where she worked on issues of global cultural governance and accountability. She participated in several international conferences devoted to the protection of cultural heritage in international law, as well as published and peer-reviewed articles on the topic.
} 


\title{
GENERAL ARTICLES
}

\author{
Berenika Drazewska
}

gation for the protection of cultural heritage. Part three offers conclusions.

Keywords: Hasankeyf, llisu dam, cultural heritage protection, development projects, human rights

\section{Introduction}

At the time of writing these words the hydroelectric dam on the Tigris river at Ilisu, in the southeastern part of Turkey, will likely soon become operational. ${ }^{1}$ Therefore, it seems that at this point little can be done to stop the flooding of the town of Hasankeyf by the Ilisu dam's floodwaters. ${ }^{2}$ Overall, filling the dam's $300 \mathrm{~km}^{2}$ reservoir would entail partial or total flooding of some 180 villages and displacement of up to 78,000 people (mostly Kurds), ${ }^{3}$ only a fraction of whom will be able to find accommodation through the government's new housing project, New Hasankeyf; ${ }^{4}$ devastation of a biologically diverse environment, including the loss of important habitats (e.g. of the endangered Euphrates soft-shelled turtle), extermination of fish, drying up of the Mesopotamian Marshes (an important ecosystem and World Heritage Site), as well as reduction of the flow of water to the downstream populations in Iraq and Syria, bringing droughts and desertification.

\footnotetext{
1 M. Shepperson, How Archaeologists Discovered an Ancient Assyrian City - And Lost It Again, "The Guardian" (international edition), 7 February 2018.

2 J. Allason, Hasankeyf, Turkey: Soon-to-be Sunken Treasure, "Financial Times", 8 March 2014; T. Arango, Turkish Dam Project Threatens to Submerge Thousands of Years of History, "New York Times", 1 September 2016, https://www.nytimes.com/2016/09/02/world/europe/turkey-hasankeyf-ilisu-dam.html [accessed: 24.02.2019].
}

3 M. Ronayne, The Cultural and Environmental Impact of Large Dams in Southeast Turkey, National University of Ireland, Galway and Kurdish Human Rights Project, London 2005, p. 67, https://aran.library.nuigalway. ie/handle/10379/1546 [accessed: 25.02.2019].

4 In 2010, the Housing Development Administration of Turkey (TOKi) began the construction of some 700 houses in the so-called New Hasankeyf, a newly constructed town about $3 \mathrm{~km}$ from the "old" Hasankeyf. However, according to the Initiative to Keep Hasankeyf Alive, persons affected by the dam are more likely than not to move away than opt for living in New Hasankeyf due to the low quality of the newly constructed buildings (having been built in haste, the houses pose a threat to their inhabitants) and the high prices of the homes, which exceed the amounts of expropriation compensation. See the Initiative to Keep Hasankeyf Alive, Report on the Current Status of the llisu Hydroelectric Power Plant Project and Hasankeyf, 11 September 2017, http://www.hasankeyfgirisimi.net/?page_id=6 [accessed: 18.02.2019]. The somewhat soulless new settlement, built on arid, rocky soil, is also a very different place compared to the "old" living heritage town with its houses surrounded by lush gardens. J. Harte, New Dam in Turkey Threatens to Flood Ancient City and Archaeological Sites, "National Geographic", 21 February 2014, https://news.nationalgeographic.com/news/2014/02/140221-tigris-river-dam-hasankeyf-turkey-iraq-water/ [accessed: 25.02.2019]. According to a survey conducted in 2012, a little over $21 \%$ of inhabitants of Hasankeyf have declared a willingness to move to the new settlement. See Doğa Derneği, Hasankeyf Survey Report, 2012, https://www.dogadernegi.org/wp-content/uploads/2015/10/HASANKEYF-SURVEY-REPORT-Summary. pdf [accessed: 13.02.2019]. I wish to thank the anonymous reviewer for bringing this report to my attention. 
But it is the losing battle to save the cultural heritage of Hasankeyf - a well-preserved ancient city of at least 10,000 years of continuous human occupation- $80 \%$ of which will disappear under water and silt after the reservoir is impounded, that has sparked the most controversy in connection with the llisu dam construction project. A Roman fortress in the ancient times, and a bustling Silk Road city in the Middle Ages, today Hasankeyf (meaning "rock fort" in Arabic) is a unique mix of cultural influences, bearing the marks of the Assyrian, Roman, Byzantine, Artuqid, Ayyubid, and Ottoman civilizations. Distinguished by its thousands of man-made cave dwellings carved into the limestone cliff, countless archaeological sites and monuments (including the 15th-century cylindrical tomb of Zeynel Bey, decorated with a pattern of colorful glazed bricks), an Ayyubid fortress and palace, and the remains of a 12th-century landmark bridge as well as its character of a living heritage town, Hasankeyf is without a doubt a place of unique cultural value. Although Veysel Eroglu, the Turkish Minister of Forestry and Water Affairs, was quoted as saying that "only primitive things" will be flooded by the dam, ${ }^{5}$ there is certainly more at stake at Hasankeyf.

The Turkish government is determined to bring the llisu hydroelectric power project to fruition for economic and political reasons. Water is Turkey's foremost resource, and through the Southeastern Anatolia Project (GAP) the government plans to use it to generate electricity, improve agriculture through better irrigation, and create jobs in the underdeveloped region of Southeastern Anatolia. As the second largest of GAP's pharaonic projects, with an expected capacity of $1200 \mathrm{MW}$ and annual production of energy of $3833 \mathrm{GWh}$, llisu is the apple of the government's eye, although critics doubt GAP will deliver on its promises to improve the quality of life of people living in the Southeast. ${ }^{6}$ This insistence on building the dam can seemingly also be linked to the government's plans to wrestle control over the region from Kurdish hands, with the construction of the dam involving destruction of an important center of Kurdish resistance ${ }^{7}$ as well as mountainous corridors facilitating the movement of Kurdistan Workers' Party fighters in the area. ${ }^{8}$

The situation at Hasankeyf has sparked vigorous protests against the dam worldwide. Turkey has been accused by journalists and NGOs of waging war by

\footnotetext{
5 G. Seufert, Das Böse kommt von draußen, "Zeit Online", 10 July 2009. That comment is illustrative of a broader tendency among the central authorities to regard only some kinds of the region's rich heritage as worth saving. For more on this, see M. Ronayne, op. cit., pp. 29-31.

6 M. Ronayne, op. cit., pp. 19-20 and N. Hildyard et al., The llisu Dam, the World Commission on Dams and Export Credit Reform: The Final Report of a Fact-finding Mission to the llisu Dam Region, Kurdish Human Rights Project, 2000, http://www.thecornerhouse.org.uk/resource/ilisu-dam-world-commission-dams-and-export-credit-reform [accessed: 24.02.2019].

7 G. Monbiot, Depraved Debt Collectors: A Shadowy Agency Underwrites Scores of Macabre Schemes, "The Guardian" (international edition), 14 October 1999, p. 22.

8 J. Warner, The Struggle over Turkey's Ilısu Dam: Domestic and International Security Linkages, "International Environmental Agreements" 2012, Vol. 12, p. 239.
} 


\title{
GENERAL ARTICLES
}

\author{
Berenika Drazewska
}

water, ${ }^{9}$ by archaeologists of ethnic cleansing, ${ }^{10}$ and has even been compared to ISIS in Kurdish media outlets. ${ }^{11}$ Opponents of the dam also juxtapose the over 10,000 years of Hasankeyf's cultural history and the mere 30-40 years of the dam's life expectancy, due to silting up.12 The project also raises important issues relating to the rules of international law governing the non-navigational uses of international watercourses, ${ }^{13}$ which have given rise to much protest downstream, in Iraq and Syria.

This paper takes a closer look at the first two (failed) attempts to construct and finance the dam, which present important aspects worthy of consideration from the point of view of international law and the protection of cultural heritage in largescale development projects. Although export credit agencies (ECAs) ${ }^{14}$ have often shown little concern for compliance with sustainability standards ${ }^{15}$ due to their mandate, which is to support domestic companies and promote trade, not to advance sustainable development, European ECAs played an important role in the international endeavors to implement such standards in the llisu dam case (1998-2009). Notably, the construction of the llisu dam involved the first ever attempt to enforce standards on cultural heritage protection in a development project through ECAs,

9 See, e.g., G. Monbiot, op. cit.; H.L. Smith, Turkish Monuments Wheeled Out of Town Before Flood 'Washes History Away,', "The Times" (UK), 8 August 2018, https://www.thetimes.co.uk/article/monuments-wheeledout-of-town-before-flood-washes-history-away-tn7cx0xzn [accessed: 26.02.2019]; P. Bosshard, A Test Case of International Policy Coherence: A Case Study of the llisu Hydropower Project (Turkey), Memorandum to the UK Parliament submitted by the Berne Declaration, March 1999, https://www.publications.parliament.uk/pa/cm199900/cmselect/cmtrdind/200/200ap07.htm [accessed: 6.02.2019].

10 Press statement by M. Hall, President of the World Archaeological Congress (the largest global organization of archaeologists), 14 November 2001.

11 AKP No Different than ISIS, Destroying Ancient Sites in Hasankeyf, "ANF News", 14 August 2017, https:// anfenglishmobile.com/kurdistan/akp-no-different-than-isis-destroying-ancient-sites-in-hasankeyf-21543 [accessed: 11.02.2019].

12 In the words of the Committee on Culture, Science and Education of the Council of Europe Parliamentary Assembly, "thousands of years of human ingenuity is being destroyed for a short-lived power project" (Council of Europe Parliamentary Assembly, Committee on Culture, Science and Education, Cultural Aspects of the llisu Dam Project, Turkey, information report, 18 December 2001, para. 6.3.2).

13 See especially Articles 5(1), 7(1), 11, and 12 of the Convention on the Law of the Non-Navigational Uses of International Watercourses, 21 May 1997, 36 ILM 700 (1997). Although Turkey has not ratified the Convention, it is not unlikely that it is bound by it insofar as it reflects customary international law. See L. Boisson de Chazournes et al., Note on Ilisu Dam Project/South-eastern Anatolia Project ("GAP"), 2 March 2007, in: Berne Declaration, WEED, ECA-Watch, Summary of the Evaluation of the Terms of Reference and Their Implementation for the llisu Dam Project in Turkey Regarding Resettlement, Environmental Issues, Cultural Heritage and Riparian Countries, 11 September 2007, Annex 3, https://goo.gl/9r7zbs [accessed: 26.02.2019].

14 Export credit agencies are government entities which use public funds to facilitate the exports of national goods and services in the framework of high-risk projects. Their loan guarantees make it safe for national exporters to compete for overseas sales.

15 The purpose of such standards is to mitigate the impact of the projects supported by the ECAs on human rights, cultural heritage, and the environment. 
and a cancellation of contracts over their noncompliance with these standards. ${ }^{16}$ This paper aims to (1) examine that attempt in detail; and (2) analyze the meaning of the llisu case for the development and implementation of standards on cultural heritage protection in infrastructure construction projects. After offering a general overview and a timeline of the llisu dam project in the first part of the paper, its second part focuses on the role of those standards in the early endeavors to construct and finance the Ilisu dam. In particular, it discusses the content of these standards, identifies their principal agents of implementation, and explains why European ECAs, banks, and corporations decided first to embark on, and later to pull out of, the project. The third part of the paper examines the case against Turkey before the European Court of Human Rights, initiated in 2006 by a group of Turkish citizens in connection with the construction of the Ilisu dam. It discusses the role and content of "common European standards" on cultural heritage protection in the adjudication of this case, and how they might be expected to influence future adjudications of human rights concerning cultural heritage by the Court. Part four concludes with some observations on what can be learned for future cases of this kind.

\section{Overview and Timeline of the Ilisu Dam Project}

In 1954, the Turkish government began feasibility studies for a hydroelectric dam on the Tigris river, in the village of Ilisu in Southeastern Anatolia - in the culturally rich Upper Mesopotamia, i.e. the cradle of civilization - with the understanding that if the dam were to be built, most of the historic town of Hasankeyf would become submerged. In 1978, Hasankeyf became a class I protected archaeological site under Turkish law. ${ }^{17}$ That designation implied a prohibition of all new construction at the site, which had to be preserved in its original state. ${ }^{18}$ However, when in 1982 the Turkish government announced it would pursue the goal of revitalization of the poor southeastern part of the country in the framework of the GAP, ${ }^{19}$ Ilisu was listed as one of the 22 hydroelectric dams to be constructed as part of the ambitious initiative. In 1998, archaeological excavations at Hasankeyf began. In the same year, the Turkish government signed an agreement with the Swiss companies Sulzer Hydro and ABB Switzerland, as a result of which the first consortium involved in the hydroelectricity project at Ilisu was born. This agreement was later terminated due to noncompliance with the project conditions on the Turkish side. In 2001, the Council of Europe's Committee on Culture, Science and Education

\footnotetext{
16 Cf. C. Eberlein et al., The llisu Dam in Turkey and the Role of Export Credit Agencies and NGO Networks, "Water Alternatives" 2010, Vol. 3(2), pp. 291, 299.

17 Decision A-1105 of the Turkish High Commission for the Preservation of Cultural Entities and Monuments (14 April 1978).

18 Law No. 2863 of 21 July 1983 on Conservation of Cultural and Natural Property (Turkey).

19 For an overview of the GAP Project, see D. Shoup, Can Archaeology Build a Dam? Sites and Politics in Turkey's Southeast Anatolia Project, "Journal of Mediterranean Archaeology" 2006, Vol. 19(2), pp. 232-233.
} 


\section{GENERAL ARTICLES}

Berenika Drazewska

prepared an information report which highlighted the importance of compliance with the conditions relating to the protection of cultural heritage in the execution of this project. ${ }^{20}$ The authors of the report observed that unlike the ancient town of Zeugma on the Euphrates, where Birecik - another GAP dam - buried precious Greco-Roman mosaics and a countless number of unstudied archaeological sites underneath its reservoir waters in 2000, ${ }^{21}$ Hasankeyf's treasures could still be saved if "the contract is [...] given to contractors who will [not] ignore these [project] conditions and [...] respect conservation of the cultural heritage". ${ }^{22}$ In March 2005, a new consortium was formed of Turkish, German, Swiss, and Austrian companies (the second Ilisu consortium) and in August 2006 the construction work began. However, in view of Turkey's persistent noncompliance with the social, cultural, and environmental project conditions, the consortium was dissolved in 2009. Due to Turkey's determination to complete the project at any cost, it was resumed again in 2010 as an all-Turkish initiative, in spite of the European Parliament's request that the work be ceased until an impact assessment is in place, ${ }^{23}$ and despite continued protests from NGOs and activists.

\section{European ECAs and the Conditions for the Financing of the llisu Project}

\section{The first consortium}

Since Turkey could not count on the World Bank's funding due to its downstream neighbors Iraq and Syria's protests against the project, it had to turn to look elsewhere for funding. Early attempts to finance the project failed due to lack of interest on the part of investors. A second attempt to attract funding led to the formation of the first consortium (1998-2002), which included the British company Balfour Beatty as consortium leader, the Italian Impregilo, Swedish Skanska, Turkish Nural, Kiska, and Tekfen, and the Union Bank of Switzerland (UBS). In 1998, the European companies applied for loan guarantees from the ECAs of their respective States to cover the financial risk. This met with intensified local, regional, and international protests in view of the expected catastrophic impacts of the dam. In the same year, the London-based "European llisu campaign" was founded as a result of concerted efforts of a number of European NGOs, including the Swiss Berne Declaration,

20 CoE Parliamentary Assembly, op. cit.

21 Other dams in Turkey have also caused destruction of ancient towns and little-studied archaeological sites. After the Atatürk dam on the Euphrates was constructed in 1989, Samosata, an ancient city of kings, has become submerged. In 2011, Allianoi - an ancient spa town located around natural hot springs, became engulfed by the waters of the llya river after the impounding of the reservoir of the Yortanli dam.

22 CoE Parliamentary Assembly, op. cit., para. 7.3.

23 See European Parliament, Resolution of 10 February 2010 on Turkey's progress report 2009, 10 February 2010, P7_TA(2010)0025, para. 16. 
the Austrian ECA-Watch, German World Economy, Ecology and Development (WEED, later to become the GegenStrömung, or CounterCurrent network) and support from a number of international civil society and activist groups. As a result of growing pressure over the expected impact of the dam from NGOs, the public, and some politicians, in January 1999 the European ECAs requested that Turkey meet four conditions before the credit guarantees for the llisu project could be granted:

1. Develop a resettlement program based on internationally accepted standards and with independent monitoring;

2. Make provisions for upstream water treatment plants to maintain water quality;

3. Consult with Syria and Iraq and ensure adequate downstream flows at all times; and

4. Produce a detailed plan to rescue and preserve as much of Hasankeyf's archaeological heritage as possible. ${ }^{24}$

In the meantime, in November 2000 the World Commission on Dams (WCD) ${ }^{25}$ published its ground-breaking report, commissioned to develop "internationally acceptable criteria, guidelines and standards, where appropriate, for the planning, design, appraisal, construction, operation, monitoring and decommissioning of dams". ${ }^{26}$ The report sounded a stark warning about the social, cultural, and ecological cost of dams, ${ }^{27}$ and highlighted the importance of participatory decision-making according to the "rights and risks" approach, whereby all stakeholders whose rights are affected by the development, and all those who face a risk imposed on them involuntarily, ought to be included in the relevant procedures. In the framework of the llisu project, NGOs took on the role of educating the public and putting pressure on decision-makers to comply with the findings of the WCD as well as other international and Turkish standards. The NGOs also drew attention to, inter alia, the contradiction between the governments refusing to fund the project through the World Bank, but willing to support it privately through their ECAs,

24 CoE Parliamentary Assembly, op. cit., Appendix 3.

25 The World Commission on Dams (1997-2001) was an independent body created upon recommendation of the International Union for Conservation of Nature and the World Bank in connection with the latter's attempt to address the high rate of failure of its development projects, and against the backdrop of the important debates on water and the environment (including a growing opposition to dams) emerging in the 1990s. The WCD was entrusted with preparing a comprehensive analysis of the impact of dams on development and attempting to reach an agreement with all stakeholders on the viability of large dams as means of meeting water and energy needs. In order for the WCD to maintain gravitas and impartiality, its composition sought to represent all geographic regions and key dam-building States, as well as the variety of stakeholders interested in dam building.

26 World Commission on Dams, Dams and Development: A New Framework for Decision-Making. The Report of the World Commission on Dams, Earthscan, London - Sterling, November 2000, p. XXX.

27 "Dams have made an important and significant contribution to human development, and the benefits derived from them have been considerable. In too many cases an unacceptable and often unnecessary price has been paid to secure those benefits, especially in social and environmental terms, by people displaced, by communities downstream, by taxpayers, and by the natural environment". Ibidem, p. XXVIII. 


\section{GENERAL ARTICLES}

Berenika Drazewska

without following the Bank's sustainability safeguards. ${ }^{28}$ Protests in the ECA States also made it clear that the taxpayers did not want their governments to support a project with such catastrophic impacts. ${ }^{29}$

Not long afterwards, the NGOs exposed Turkey's failure to meet the requested social, environmental, and cultural impact conditions. No appropriate mitigation measures had been implemented, and basic documents were missing. In the face of growing international opposition to the project as being in violation of international (and Turkish) standards, the main contractor, British engineering company Balfour Beatty, decided it was "not in the best interests of its stakeholders to pursue the project further", as meeting the conditions would not be possible without "substantial extra work and expense and considerable further delay", ${ }^{30}$ and together with the Italian civil engineering company Impregilo withdrew from the project at the end of 2001. After the Swiss UBS pulled out of the project amid further concerns, ${ }^{31}$ the consortium fell apart in 2002. Nevertheless, Turkey expressed its intention to continue with the project as soon as new financing was found.

\section{The second consortium}

In 2005, a second consortium composed of German, Swiss, Austrian, and Turkish companies was formed. ${ }^{32}$ The European members of the consortium again applied for export credit guarantees from their respective national ECAs, ${ }^{33}$ and for export loans from European banks: German DekaBank, Austrian Bank Austria Creditanstalt, Italian UniCredit, and French Société Générale, as well as two Turkish banks, Akbank and Garantibank. Due to pressure from members of the German, Swiss, and Austrian governments, as well as from the exporting companies to approve the export risk guarantees, the ECAs decided to take on the project. The ECAs own active involvement in the United Nations Environment Programme's follow-up process to the WCD, and the common fear that if Europe refused to help Turkey would turn to China, which would build the dam without any concern for environmental, cultural, and social standards, ${ }^{34}$ may also have been a factor in their

\footnotetext{
28 P. Bosshard, op. cit.

29 Ibidem.

30 See CoE Parliamentary Assembly, op. cit., Appendix 4 (statement of Balfour Beatty, 13 November 2001).

31 Swiss Bank Quits Turkish Dam Project, "BBC News", 27 February 2002, http://news.bbc.co.uk/2/hi/europe/1844465.stm [accessed: 20.02 .2019 ].

32 The second consortium included the Austrian VA Tech, Swiss Alstom, Stucky, Colenco, and Maggia, German Züblin AG, and Turkish Nurol, Cengiz, Celikler, and Temelsu.

33 The European ECAs were: the German Euler Hermes AG, the Swiss SERV (Swiss Export Risk Insurance), and the Austrian ÖKB (Österreichische Kontrollbank).

34 These were recurring fears throughout the llisu project, revived after the collapse of the second consortium (see, e.g., L. Harris, Turkey: Government Looks to China as Europe Suspends Funding for Ilisu Dam, "Art Newspaper", 18 September 2009).
} 
decision. ${ }^{35}$ However, having learned their lesson from the first consortium and due to pressure by NGOs, ${ }^{36}$ the ECAs requested from the outset that Turkey fulfill a set of project conditions relating to the social, environmental, and cultural impacts of the project, modeled after the World Bank standards, ${ }^{37}$ and submit to a strict periodic monitoring procedure, with three subcommittees separately examining issues of resettlement, cultural heritage, and the environment. The credit guarantees would thus be granted only if Turkey agreed to and enforced standards on dam construction relating to its impact on the affected people (including downstream riparian States), cultural heritage, and the environment. The ECAs also resolved to take their decisions jointly. Typically, ECAs come much later into a project (when it is time to insure the exporters' deliveries of goods or services overseas), and so their role is usually limited to requesting that exporters demand compliance with international best practices. ${ }^{38}$ What was therefore remarkable about the role of ECAs in the llisu case is that by requesting the project conditions at an early stage of their involvement, they were able to shape the process and its outcome in line with some of the best practices and the concerns over the human, cultural, and ecological costs of the project as voiced by the NGOs and the public. ${ }^{39}$

In return for "in principle" credit guarantees, in an agreement with the ECAs signed in October 2006 ("the 2006 Agreement") the Turkish government committed to fulfilling 160 conditions, or Terms of Reference (ToR), to bridge the gap between the standards applicable in Turkey and those used by the World Bank in such situations to mitigate the negative impacts of the project. ${ }^{40}$ Thirteen of these conditions were related to cultural heritage. ${ }^{41}$ The implementation of the ToR was to take place according to two deadlines: 27 conditions were to be met within 18 months from signing the agreement (by March 2008), and the remaining 133 before the construction was commenced. ${ }^{42}$ This incremental approach was criticized as contrary to World Bank policies, which recommend compliance before the final financial com-

\footnotetext{
35 See C. Eberlein et al., op. cit., p. 301.

36 M. Ronayne, N. Ascherson, Opposition to Turkey's llisu Dam Rises Again, "China Dialogue", 1 September 2006, https://www.chinadialogue.net/article/show/single/en/336-Opposition-to-Turkey-s-llisu-Dam-rises-again [accessed: 26.02 .2019$]$.

37 World Bank, Environmental and Social Framework (Washington 2017) is the most recent safeguard policy document for project assessment. It applies to all new World Bank projects as of 1 October 2018.

38 C. Eberlein et al., op. cit., p. 300.

39 Ibidem.

40 M. Garen, M.-H. Carleton, Deep Divide, "Financial Times", 21 March 2008.

41 See the following subsection.

42 As far as the ToR pertaining to cultural heritage were concerned, Turkey was only required to provide the legal basis for relocation of monuments before the final commitment of the ECAs. See Berne Declaration, WEED, ECA-Watch, Summary of the Evaluation of the Terms of Reference and Their Implementation for the Ilisu Dam Project in Turkey Regarding Resettlement, Environmental Issues, Cultural Heritage and Riparian Countries, 11 September 2007, p. 14, https://goo.gl/9r7zbs [accessed: 26.02.2019].
} 


\section{GENERAL ARTICLES}

Berenika Drazewska

mitment is made. Upon signing the 2006 Agreement, there had been no proper resettlement plan and no appropriate environmental impact assessment (EIA) for Ilisu (the ElA prepared in 2005 by the National Water Administration pursuant to Turkish Environmental Law from 1983 fell short of World Bank's standards), and no cultural heritage impact assessment whatsoever, in spite of such a requirement under international law. ${ }^{43}$ In case of Turkey's default on any of the social, cultural, and environmental conditions, the 2006 Agreement stipulated that both the ECAs and the European banks, which granted export loans, would withdraw from the project.

Terms of Reference on the protection of cultural heritage and the expert review by NGOs

In light of the ToR related to cultural heritage, Turkey was required to, inter alia:

- provide baseline data on the archaeological finds in the affected area;

- submit a comprehensive Cultural Heritage Action Plan for all archaeological surveys and excavations, including a time schedule, responsible personnel, budgets, etc.;

- submit a list of involved institutions and their responsibilities, and coordinate their work;

- submit a plan for the investigation and excavation of mounds;

- ensure the availability of experts to supervise the archaeological works and to deal with chance finds;

- ensure that $50 \%$ of the workers were persons affected by the project;

- provide the legal basis for the relocation of monuments;

- carry out ethnographic studies by conducting interviews with the population to collect the history of the villages and the stories of the people;

- develop a concept for the Cultural Park;

- provide monitoring reports on the surveys and excavations, the rebuilding of monuments in the Cultural Park, and the Park's construction and operation. ${ }^{44}$

Although a step in the right direction, these predominantly technical requirements did not exhaustively address the challenges of protecting the cultural heritage of Hasankeyf. An expert review launched by the Berne Declaration, ECA-Watch Austria, WEED, and other NGOs after the 2006 Agreement was concluded identified a series of shortcomings in the ToR, and the cultural heritage provisions were no exception. ${ }^{45}$ Among the shortcomings identified by the NGOs were: lack of any clear indicators as to how cultural heritage was to be safeguard-

43 See the CoE Convention for the Protection of the Archaeological Heritage of Europe, 16 January 1992, CETS 143 ("the Valletta Convention"), art. 5(iv).

44 Berne Declaration, WEED, ECA-Watch, op. cit., p. 14.

45 The expert review of the ToR was entrusted to Christine Eberlein of the Berne Declaration. For a summary of the report, see ibidem. 
ed, leaving a lot to the discretion of the Turkish authorities (for example, the decision about which monuments were to be salvaged before the flooding); lack of a requirement to undertake mitigation measures for the monuments at risk of submersion, and to consult with the relevant NGOs and the affected groups. ${ }^{46}$ This latter point was particularly important, as according to a survey conducted at Hasankeyf in 2012 by the environmental organization Doğa Derneği, the majority of the town's population is against the dam and the government's plans toward the site's cultural heritage and resettlement; $67.8 \%$ of respondents stated they did not want to leave Hasankeyf. ${ }^{47}$ However, the locals have generally been excluded from any relevant decision-making processes. ${ }^{48}$ Furthermore, alleged security considerations allowed the government to limit access to the site and crack down on protests against the dam project, especially after the proclamation of the state of emergency following the 2016 coup. ${ }^{49}$ The review by NGOs also noted that the ToR ignored the importance of Hasankeyf's particular setting for its cultural value, failed to entertain the option of in situ preservation as per current international and Turkish law, ${ }^{50}$ and did not consider the matter of feasibility of the relocation of monuments.

\section{Turkey's international obligations towards cultural heritage}

As signaled by the NGOs, the lack of assurances of adequate protection of the rich and diverse heritage of Hasankeyf was probably the most salient shortcoming of the ToR. Although the Turkish government has arranged for several of the monuments to be moved to a cultural park adjoining the "New Hasankeyf" settlement, ${ }^{51}$ this does not guarantee that destruction and damage will be avoided. Experts have consistently voiced concerns about the feasibility of such plans, ${ }^{52}$ and the authen-

\footnotetext{
46 Ibidem, pp. 14-18.

47 Doğa Derneği, op. cit., fig. 1.

48 In the words of the mayor of Hasankeyf: "Since the beginning of this project, no one from the people living here is involved. We always face trouble when we try to get information about the project. We have not been informed by the officials". See M. Garen, M.-H. Carleton, op. cit.

49 Initiative to Keep Hasankeyf Alive, op. cit.

50 See Law No. 2863, para. 20 and the Valletta Convention, art. 5(iv).

51 The short list of monuments to be saved includes the Zeynel Bey tomb, the Artuqid Hammam, the Kızlar, El Rizk and Sultan Suleyman mosques, as well as the Orta Kapi and the Imam Abdullah Zaviya (a small Islamic school). Most of these monuments have already been relocated.

52 According to Prof. Abdusselam Ulucam, current head of excavations at Hasankeyf, the major monuments cannot be moved without destroying them, as the rock is too fragile (M. Garen, M.-H. Carleton, op. cit.). According to Ercan Ayboga, a hydrologist and spokesperson for the Initiative to Keep Hasankeyf Alive, the monument relocation plan is "totally impractical and technically impossible": the particular masonry, which involves stone blocks molded to fit together, means that they cannot be taken apart and then put together without some of them breaking and no longer fitting in with the others. See D. Bolz, Endangered Site: The City of Hasankeyf, Turkey, "Smithsonian Magazine", March 2009, https://www.smithsonianmag. com/travel/endangered-site-the-city-of-hasankeyf-turkey-51947364/ [accessed: 6.02.2019].
} 


\title{
GENERAL ARTICLES
}

\author{
Berenika Drazewska
}

ticity and integrity of the monuments in a new setting. According to Prof. Zeynep Ahunbay, an archaeologist,

[s]iting and topography are very important in moving monuments or parts thereof. A relocated building seldom has the same topographic relationship to its new site. When monuments are cut off from their foundations and erected on a completely different site, they look very different. They are alienated/isolated and lose much of their dignity and integrity. Their aesthetic value is diminished. A similar landscape and context has to be created in order to make them impressive and meaningful again. There are no studies or preparations to provide a similar landscape for the monuments; if the projected plan is put into execution, the new open air museum of "Hasankeyf" will be just a small park in which small fragments of great monuments will be exhibited like museum pieces..$^{53}$

In any case, a great majority of sites will find themselves underwater after the reservoir is impounded. Both scenarios raise important questions of protection and respect for cultural heritage and its surroundings, as well as ensuring access to it.

In spite of the silence of the ToR on the matter of providing adequate protection to Hasankeyf's heritage, Turkey is (and was back in 2006 as well) a party to the World Heritage Convention ${ }^{54}$ and the Intangible Heritage Convention, ${ }^{55}$ as well as to a number of conventions on the protection of cultural heritage adopted by the Council of Europe (CoE), and thus had specific obligations toward the city based on these international instruments. Turkey ratified the World Heritage Convention in 1983. Although no proposal to nominate Hasankeyf for inscription on the World Heritage List was ever put forward, according to independent analysis the site fulfills 9 out of 10 criteria used by the World Heritage Committee to identify the Outstanding Universal Value of sites eligible for such inscription. ${ }^{56}$ Hasankeyf would seem to tick multiple boxes in the World Heritage Convention's definition of cultural heritage in its Article 1, as it includes "architectural works, works of monumental sculpture and painting, elements or structures of an archaeological nature, inscriptions, cave dwellings and combinations of features" as well as groups of buildings; moreover, the seamless blending of the cultural and natural elements in its unique cityscape could warrant the qualification as a mixed cultural and natural site, ${ }^{57}$

\footnotetext{
53 Z. Ahunbay, Hasankeyf, a Site Threatened by the llisu Dam Project, in: M. Petzet, J. Ziesemer (eds.), Heritage at Risk: ICOMOS World Report 2006-2007 on Monuments and Sites in Danger, E. Reinhold-Verlag, Altenburg 2008, p. 156. For similar comments by Prof. Olus Arik, see P. Young, Hasankeyf: A City in Peril," History Today" 2000, Vol. 50(11), pp. 3-4.

${ }^{54}$ Convention Concerning the Protection of the World Cultural and Natural Heritage, 16 November 1972, 1037 UNTS 151.

55 Convention for the Safeguarding of Intangible Cultural Heritage, 17 October 2003, 2368 UNTS 1.

56 See Z. Ahunbay, Ö. Balkız, Outstanding Universal Value of Hasankeyf and the Tigris Valley, Doğa Derneği 2009, https://goo.gl/qZ9tqX [accessed: 26.02.2019].

57 World Heritage Committee, Operational Guidelines for the Implementation of the World Heritage Convention (2017), para. 46.
} 
or possibly even a cultural landscape ("combined work of nature and man", which is "illustrative of the evolution of human society and settlement over time"). ${ }^{8}$ In light of the World Heritage Convention, the duty to identify, protect, conserve, present, and transmit to future generations any such heritage should involve doing everything in a State Party's power, ${ }^{59}$ and is certainly not fulfilled by uprooting and relocating a few selected monuments to an artificial park, abandoning all others to be engulfed.

Similarly, as party to the CoE's Valletta Convention since 2000,60 Turkey is obliged to protect its archaeological heritage, which is defined as "all remains and objects and any other traces of mankind from past epochs [...]", not just a select few, which should also be "protected together with their context"61 - i.e., not relocated. As party to the European Cultural Convention, Turkey is also required to "take appropriate measures to safeguard and to encourage the development of its national contribution to the common cultural heritage of Europe", which the whole of Hasankeyf certainly is. ${ }^{62}$ The failure to grant archaeologists enough time or resources to study the sites to be affected by the construction work is also at odds with Turkey's commitments under the Valletta Convention. ${ }^{63}$ In light of the Valletta Convention Turkey is required to ensure the participation and consultation of archaeologists at every stage of the development project; ${ }^{64}$ and in particular to ensure that potentially destructive techniques are carried out only by qualified, specially authorized persons. ${ }^{65}$ Yet according to Zeynep Ahunbay, the process for the relocation of monuments has not been based on appropriate expertise. ${ }^{66}$ In light of both the Valletta Convention and the European Cultural Convention, Turkey should ensure access to the heritage, ${ }^{67}$ which also follows from its

\footnotetext{
58 Ibidem, para. 47.

59 World Heritage Convention, art. 4.

60 Valletta Convention, art. 5(ii)b. The Valletta Convention is particularly relevant to determining Turkey's obligations to safeguard heritage in the context of the llisu dam, as it is the product of a revision of the earlier London Convention (1969), launched after it had become clear that the most serious threat to archaeological heritage nowadays came from large development projects, not illicit excavations, as was the case in the 1960s.

61 Ibidem, art. 1.

62 CoE European Cultural Convention, 19 December 1954, ETS 18 (Turkey has been a party since 1957).

63 As Prof. Olus Arik, former head of excavations at Hasankeyf, said back in 2000: "We need a minimum of fifty years here and we have just nine or ten - unless of course we can stop the dam". See P. Young, op. cit.

64 Valletta Convention, art. 5.

65 Ibidem, art. 3.

66 See Z. Ahunbay, Observations Concerning the "Agreed Minutes of the Final Assessment Meeting (FAM) Regarding Ilısu Dam and Hydroelectric Power Plant Project", 5 August 2007, in: Berne Declaration, WEED, ECA-Watch, op. cit., Annex 2.

67 Valletta Convention, art. 9(ii); European Cultural Convention, art. 5.
} 


\title{
GENERAL ARTICLES
}

\author{
Berenika Drazewska
}

obligation as party to the International Covenant on Economic, Social and Cultural Rights to ensure the right to take part in cultural life..$^{68}$

Indeed, the cultural value of Hasankeyf transcends the monuments and cliffside caves. While its hundreds of yet unstudied archaeological sites ought to be protected as material cultural heritage, the information on human history that their analysis could have provided may be more appropriately defined as intangible cultural heritage, ${ }^{69}$ i.e.

the practices, representations, expressions, knowledge, skills - as well as the instruments, objects, artefacts and cultural spaces associated therewith - that communities, groups and, in some cases, individuals recognize as part of their cultural heritage. This intangible cultural heritage, transmitted from generation to generation, is constantly recreated by communities and groups in response to their environment, their interaction with nature and their history, and provides them with a sense of identity and continuity, thus promoting respect for cultural diversity and human creativity. ${ }^{70}$

Furthermore, Kurdish oral histories and traditions, which are vital for keeping the Kurdish identity alive, are replete with references to the topography of Hasankeyf. ${ }^{71}$ It is the original setting for the 17th-century Kurdish literary poem Mem u Zin, known and performed by the locals to this day. ${ }^{72}$ The value placed in maintaining the traditional, unique way of life is clear considering that in disregard of the government's orders that the cliffside cave dwellings be vacated, some of them were still clandestinely inhabited even very recently. ${ }^{73}$ In light of a recent survey, their strong attachment to Hasankeyf and their conviction that "their past is here" were the primary reasons why the locals did not want to be resettled in connection with the construction of the llisu dam (mentioned by $99.6 \%$ and $93.8 \%$ of the respondents objecting to the move, respectively), as was the desire to remain close to their holy places and graves (88.4\%). ${ }^{74}$ When Hasankeyf is flooded, the people's link with the place will become severed, and the intangible heritage dispersed. The Turkish government did not take the intangible aspect of the heritage of Hasankeyf into con-

\footnotetext{
68 United Nations Committee on Economic, Social and Cultural Rights, General Comment No. 21, Right of Everyone to Take Part in Cultural Life (art. 15, para. 1a of the Covenant on Economic, Social and Cultural Rights), 21 December 2009, E/C.12/GC/21, paras 6 and 15.

69 See J. Blake, International Cultural Heritage Law, Oxford University Press, Oxford 2015, p. 10.

70 Intangible Heritage Convention, art. 2.

71 For examples, see Sarah Elliott who in 2005 carried out fieldwork (qualitative interviews with the inhabitants) in Hasankeyf: S. Elliott, Damming Ava Mezin. Challenges to Safeguarding Minority Intangible Cultural Heritage in Turkey, in: M.L. Stefano, P. Davis (eds.), The Routledge Companion to Intangible Cultural Heritage, Routledge, London 2017, pp. 174-175.

72 Ibidem, p. 167.

73 See J. Allason, op. cit.

74 Doğa Derneği, op. cit., fig. 2.
} 
sideration. ${ }^{75}$ Although the ToR did not specifically mention intangible cultural heritage, as party to the Intangible Heritage Convention Turkey was (and still is) under an obligation to take all necessary measures to ensure the safeguarding of this kind of heritage present in its territory. ${ }^{76}$ Safeguarding includes ensuring the viability of the intangible cultural heritage, including the identification, documentation, research, preservation, protection, promotion, enhancement, transmission, particularly through formal and non-formal education, as well as the revitalization of the various aspects of such heritage, ${ }^{77}$ with the involvement of affected communities. ${ }^{78}$

Overall, the ToR's requirements relating to cultural heritage were too lenient considering Turkey's binding commitments under international law. They also fell short of the WCD's recommendations and the World Bank standards. ${ }^{79}$ NGO representatives also emphasized that the project never would have been considered acceptable in the European countries financing the dam, and was not even in line with the members of the consortium's own sustainability commitments. ${ }^{80}$

\section{Collapse of the second consortium}

On-site inspections of the committee of experts, ${ }^{81}$ as well as constant scrutiny from the anti-llisu campaign ${ }^{82}$ revealed that also this time, Turkey was in violation of a great majority of the social, environmental, and cultural project conditions requested by the ECAs. In December 2008, the German, Austrian, and Swiss ECAs suspended their credit guarantees, giving the Turkish government a 180-day ultimatum to conform with the standards. ${ }^{83}$ However, Turkey persisted in violating the standards it had committed to. In the face of continued pressure from NGOs,

\footnotetext{
75 See S. Elliott, op. cit., footnote 7.

76 Intangible Heritage Convention, art. 11.

77 Ibidem, art. 2.

78 Ibidem, art. 11.b.

79 In light of the then-applicable Operational Policy Note 11.03: Management of Cultural Property, the World Bank's general policy regarding cultural properties (sites of archaeological, historical, religious, or cultural significance) was to "assist in their preservation and seek to avoid their elimination".

80 See C. Eberlein et al., op. cit., p. 304, and P. Bosshard, op. cit., who quotes an official statement given to UNEP by the then CEO of UBS (the main creditor) in 1998: "UBS now applies the most stringent environmental requirements of either the World Bank, the host country, or any OECD country".

81 See CoE, Sub-Committee on Cultural Heritage, llisu Hydropower Project, Turkey: Report Prepared on Behalf of Euler Hermes (Germany), OeKB (Austria) and SERV (Switzerland), first site visit, Dec. 2-11, 2007, 4 February 2008, http://m-h-s.org/ilisu/upload/PDF/Analysen/Bericht_Kulturelles_Erbe.pdf [accessed: 19.02.2019] and CoE, Sub-Committee on Cultural Heritage, llisu Hydropower Project, Turkey: Report Prepared on Behalf of Euler Hermes (Germany), OeKB (Austria) and SERV (Switzerland), second site visit, Aug. 10-21, 2008, 20 October 2008, http://m-h-s.org/ilisu/upload/PDF/Analysen/Bericht_KulturellesErbe_Okt2008.pdf [accessed: 19.02.2019].

82 See C. Eberlein et al., op. cit., pp. 304-307.

83 Insurers Halt Work on Turkish Dam, "BBC News", 24 December 2008, http://news.bbc.co.uk/2/hi/europe/7798857.stm [accessed: 20.02.2019].
} 


\section{GENERAL ARTICLES}

Berenika Drazewska

the European ECAs invoked the environmental default clause of the 2006 Agreement and withdrew the $€ 450$ million in financial guarantees in July 2009. As a result of the ECAs' decision, export credit from their three domestic banks was equally cut off; and the three European banks - DekaBank, Bank Austria, and Société Générale - announced that "in line with the decision of the Export Credit Agencies, the three banks will apply the mechanism foreseen in case the contractually agreed measures ensuring the World Bank guidelines on environment, resettlement and cultural heritage are not fully implemented" ${ }^{84}$ Supply contracts with the consortium participants were also terminated.

The withdrawal of the ECAs was a great victory for the NGOs and activists, who described it as "the only correct signal". ${ }^{85}$ The then-German Minister of Development Cooperation, Heidemarie Wieczorek-Zeul, spoke with approval of the withdrawal of guarantees: "If protection of people, the environment and cultural heritage cannot be assured, supply and loan guarantee agreements for the dam must be terminated", adding that she felt vindicated in her critical approach to the project from the start. ${ }^{86}$ "Süddeutsche Zeitung" called the withdrawal long overdue, observing that a similar project never would have been permitted in Germany ${ }^{87}$ In the words of left-wing "Frankfurter Rundschau", "a small but persistent grassroots movement has seen to it that the German government cannot quietly set aside ecological and social standards evidently applied at home, while providing export aid to German construction companies doing business abroad" ${ }^{88}$ On the other side, the Turkish Minister of Forestry and Water Affairs, Veysel Eroğlu, assured that the dam would yet be built, dismissing the withdrawal of guarantees as a sign of Europe's disagreement with Turkey's role as a regional power. ${ }^{89}$

\section{Further attempts of NGOs to enforce compliance with standards}

After the collapse of the second consortium, NGOs sought to explore new venues and processes to try to pressure Turkey to comply with heritage protection standards at Hasankeyf. In 2010 and 2011, European NGOs and activists from areas to be affected by the construction of the dam submitted written observations to the Committee on Economic, Social and Cultural Rights (CESCR) in reaction to the report on the measures of implementation of the International Covenant

\footnotetext{
84 DekaBank, Bank Austria, Société Générale, Press Release of 7 July 2009, https://goo.gl/XSsrce [accessed: 6.03.2019].

85 Keine Garantien für umstrittenen llisu-Damm, "Neue Zürcher Zeitung", 7 July 2009.

86 G. Höhler, V. Gaserow, Berlin legt Ilisu-Staudamm trocken, "Frankfurter Rundschau", 7 July 2009.

87 D. Lindsey, The Turkish Dam That "Would Never Have Been Permitted" in Germany, "Spiegel Online", 8 July 2009, http://www.spiegel.de/international/world/the-world-from-berlin-the-turkish-dam-that-wouldnever-have-been-permitted-in-germany-a-635054.html [accessed: 6.03.2019].

88 Ibidem.

89 G. Seufert, op. cit.
} 
on Economic, Social and Cultural Rights (ICESCR) submitted to the Committee by Turkey in its capacity of Party to the Covenant. ${ }^{90}$ In their observations, presented at a Pre-Sessional Working Group of the Committee in 2010,91 the Initiative to Keep Hasankeyf Alive and GegenStrömung (CounterCurrent) raised a number of concerns as to the llisu dam construction process in the context of Turkey's obligations under Article 15 ICESCR (right to cultural life) as explained by the Committee in its General Comment No. 21, ${ }^{92}$ including violation of the duty to respect and protect cultural heritage, ${ }^{93}$ to ensure access to it, ${ }^{94}$ and to ensure participation of the affected communities in relevant decision-making processes. ${ }^{95}$ The following year, in collaboration with several other NGOs and associations, the Initiative to Keep Hasankeyf Alive and GegenStrömung produced a report on the impact of dam construction in Turkey on economic, cultural, and social rights, which was considered at the 46th session of the Committee. ${ }^{96}$ This report also raised concerns regarding the Ilisu dam, pointing out that the monuments at Hasankeyf were gravely threatened both by the floodwaters and by the government's plans to relocate some of them to the cultural park, and that the dam's construction should not continue until appropriate impact assessments and feasible mitigation strategies were in place. ${ }^{97}$ For now the Committee is still considering the issue, but even though during its 46th session it has expressed deep concern over the potential impact of the llisu dam on cultural (and other) rights, ${ }^{98}$ its final recommendation will not be binding on Turkey. ${ }^{99}$

90 Pursuant to Article 16 ICESCR, the Parties submit reports on the measures adopted and the progress made in achieving the observance of the rights warranted under the Covenant.

91 Initiative to Keep Hasankeyf Alive, GegenStrömung - CounterCurrent, Proposed Questions to the Government of the Republic of Turkey Regarding Economic, Social and Cultural Rights of the Population Affected by Large Dams, Notably the llisu Hydropower Plant, 29 April 2010, pp. 6-7, https://goo.gl/z8ookk [accessed: 6.03.2019].

92 In recognizing access to cultural heritage as necessary for the fulfillment of the right to take part in cultural life, General Comment No. 21 provides the link between the obligation under Article 15 ICESCR and the protection of cultural heritage (or cultural goods). CESCR, General Comment No. 21..., paras 6, 16(a), 49(b), (d), (e), 50(a), (b), 54(b).

93 Ibidem, paras 50(a) and (b).

94 Ibidem, paras 6, 16(a), (b), 49(b), (d).

95 Ibidem, paras 15(c), 49(e), 54(a), 55(e).

96 CounterCurrent - GegenStrömung et al., Dam Construction in Turkey and Its Impact on Economic, Cultural and Social Rights. Parallel Report in Response to the Initial Report by the Republic of Turkey on the Implementation of the International Covenant on Economic, Social and Cultural Rights, 14 March 2011, https://goo.gl/qYWJwy [accessed: 6.03.2019].

97 Ibidem, para. 37.

98 CESCR, Consideration of Reports Submitted by States Parties under Articles 16 and 17 of the Covenant: Concluding Observations of the Committee on Economic, Social and Cultural Rights: Turkey, 12 July 2011, E/C.12/ TUR/CO/1, para. 26.

99 For a thorough description of the involvement of the NGOs in the proceedings before the CESCR (and for a general discussion on the limits of the human rights approach with regard to preventing the 


\section{GENERAL ARTICLES}

Berenika Drazewska

In 2017, with the support of Turkish NGOs the European cultural heritage NGO network Europa Nostra decided to qualify "ancient city of Hasankeyf and its surroundings" as one of the seven most endangered sites in Europe in 2016. ${ }^{100}$ In the statement justifying the decision, the Board of Europa Nostra "deeply deplores" Turkey's decision to build the llisu dam, which will lead to the loss of Hasankeyf, a site "not just of national and European but of world significance", and observes that the relocation of the Zeynel Bey tomb from Hasankeyf to the cultural park has been completed without sufficient documentation or consultation with the local and scholarly communities, while other important monuments at the site remain at great risk. ${ }^{101}$ Therefore, Europa Nostra "urges the Turkish authorities to adhere to the standards of heritage protection which are included in the European Conventions [adopted under the auspices of the $\mathrm{CoE}$ ] and to set up a proper consultation process with local communities and civil society organisations concerned in an open and transparent manner". ${ }^{102}$

\section{The Petition to the European Court of Human Rights}

In 2006, a group of Turkish citizens concerned about the fate of Hasankeyf filed a petition with the European Court of Human Rights (ECtHR) against Turkey, Austria, and Germany ${ }^{103}$ in connection with the construction of the llisu dam. In a decision taken by majority of a chamber composed of seven judges in 2019 ("Ahunbay et al. 2019 Decision"104), the ECtHR decided to reject the petition on grounds of inadmissibility ratione materiae with the provisions of the European Convention on Human Rights (ECHR) pursuant to its Article 35(3)(a) and (4). ${ }^{105}$ The spokesper-

destruction of Hasankeyf), see B. Aykan, Saving Hasankeyf: Limits and Possibilities of International Human Rights Law, "International Journal of Cultural Property" 2018, Vol. 25, pp. $22-25$.

100 The "List of 7 Most Endangered Sites in Europe" is a program run by Europa Nostra together with the European Investment Bank Institute and the CoE Development Bank with support of one of the European Union's cultural programs since 2013 to identify sites and monuments at greatest risk in Europe and mobilize public and private actors in the quest for their safeguarding by "power of example" (http://7mostendangered.eu).

101 Europa Nostra's Board Gives Statement on the Endangered Heritage Site of Hasankeyf, Turkey, Europa Nostra, 29 June 2017, http://www.europanostra.org/europa-nostras-board-gives-statement-endangered-heritage-site-hasankeyf-turkey [accessed: 6.03.2019].

102 Ibidem.

103 The Court rejected the petition with regard to Austria and Germany. See Ahunbay and Others v. Turkey, Austria and Germany, Application No. 6080/06, Decision of 21 June 2016, para. 94 (available in French).

104 Ahunbay and Others v. Turkey, Application No. 6080/06, Decision of 29 January 2019 (communicated 21 February 2019) (available in French).

105 European Convention on Human Rights, 4 November 1950, 213 UNTS 221. The applicants initially identified their petition as falling within the scope of Articles 1, 2, 5, 9, 10, and 19 of the Convention and Article 2 of Protocol 1 to the Convention. Initially, the ECtHR qualified the case as more relevant to Article 8 (right to private and family life), as well as Article 10 (freedom of expression) ECHR. In the Ahunbay et al. 2019 Decision, the Court seems to have decided that the case lends itself better to examination 
son for the Initiative to Keep Hasankeyf Alive, Ercan Ayboga, commented that the Court flinched from taking responsibility for stopping Ilisu and saving Hasankeyf "unarguably one of the most important heritage sites in Turkey, the Middle East, and Europe and [...] much more valuable than any economic investment" ${ }^{106}$ Admittedly, this outcome is a letdown, as it comes at a moment when the flooding of Hasankeyf could yet be stopped (or at least postponed), even if it was handed down 13 years after the petition was filed by the applicants. However, it is even more disappointing considering that a partial decision in the case, adopted in 2016 ("Ahunbay et al. 2016 Decision"107) also by a chamber of seven judges, may have led one to hope that Strasbourg would have written a different end to the Hasankeyf saga. There were two reasons for this: its approach to the notion of "victim" within the meaning of the Convention, and anticipation of an interpretation of the ECHR as involving a universal right to access cultural heritage.

\section{A petition in the public interest}

According to the admissibility criteria for petitions brought before the Court, a victim is a person or persons "directly or indirectly affected by the alleged violation". 108 Although the Court has accepted petitions lodged in the public interest in the past, it nonetheless seems to require that the applicant(s) have a direct link to a case, one going beyond professional interest. For instance, the Court has accepted a petition submitted in the public interest (protection of the environment) in L'Erablière v. Belgium by an association whose concern with the case was borne out by its statutory documents, and whose members were all residents of the municipalities likely to be affected by the impugned measure (extension of a landfill site), ${ }^{109}$ so it was not truly an actio popularis, which is not permitted by the Court. ${ }^{110}$ By contrast, in a case where a Greek association active in the field of protection and maintenance of the monuments and works of art connected with the history of Athens sought the return of the Elgin Marbles to Greece, the Court rejected the case on grounds of inadmissibility, observing that none of the articles cited by the applicant (Articles 8 ,

in light of Article 8 ECHR and Article 2 Protocol 1 (right to education) after all, no longer mentioning Article 10 ECHR.

106 E. Ayboga, European Court for Human Rights Rejects Appeal for Conserving Hasankeyf - An Act of Ignorance and Irresponsibility, 21 February 2019, http://www.hasankeyfgirisimi.net/?p=784 [accessed: 25.02.2019].

107 Ahunbay and Others v. Turkey, Austria and Germany, Application No. 6080/06, Decision of 21 June 2016. In that decision, the Court has given formal notice of the application to Turkey and invited it to submit written observations before giving a final judgment; see ECtHR, Rules of Court, 1 August 2018, https://www. echr.coe.int/Documents/Rules_Court_ENG.pdf [accessed: 6.03.2019], art. 54(2)(b).

108 See Article 34 ECHR and ECtHR, Practical Guide on Admissibility Criteria (updated 31 December 2018), para. 15, https://www.echr.coe.int/Documents/Admissibility_guide_ENG.pdf [accessed: 26.02.2019].

109 L'Erablière A.S.B.L. v. Belgium, Application No. 49230/07, Judgment of 24 February 2009, paras 28-30.

110 Cf. ECtHR, Practical Guide..., para. 30. 


\section{GENERAL ARTICLES}

Berenika Drazewska

9, 10, and $13 \mathrm{ECHR}$ and Article 1 of Protocol 1) "give rise to any right for an association in the position of the applicant to have the Marbles returned to Greece". 111 The applicants in Ahunbay et al. v. Turkey were "persons concerned about the different works and projects which deal with the archaeological site of Hasankeyf"112 and thus did not qualify as "victims" within the meaning traditionally given to the term in order to establish standing before the Court, ${ }^{113}$ and - to the best of the author's knowledge - did not reside in the Hasankeyf area. According to the applicants themselves, if Hasankeyf were to be destroyed, in view of its historical and scientific importance they would personally suffer, just like the rest of humanity. ${ }^{114}$ That the Court did not immediately declare the application inadmissible in view of its actio popularis (as well as essentially anticipatory) nature, appeared to foreshadow an unorthodox approach to the question of who may qualify as a victim of a violation of cultural rights.

\section{Rights to cultural heritage and the dynamic interpretation of the ECHR}

The case Ahunbay et al. v. Turkey was not the Court's first opportunity to tackle the relationship between cultural heritage and human rights. Although the ECHR does not expressly mention cultural rights, and as the report of the ECtHR Research Division on the Court's jurisprudence on cultural rights observes "the Court has never recognised the right to the protection of cultural and natural heritage as such", ${ }^{115}$ "through a dynamic interpretation of the different Articles of the Convention, [it] has gradually recognised substantive rights which may fall under the notion of 'cultural rights' in a broad sense". ${ }^{116}$ In one such case, the Court affirmed that States have duties as regards the conservation of cultural heritage, with a view to the preservation of the historical, cultural, and artistic roots of a region and its inhabitants. ${ }^{117}$ In another case, which involved an applicant's involuntary flight from the village where he had lived together with his family and where his ancestors' graves were located, and in which he was denied the right to return to the area, the Court found that 'the applicant's cultural and religious attachment with his late relatives' graves in Gulistan may also fall within the notion of 'private and family life'" (Arti-

\footnotetext{
111 Syllogos Ton Athinaion v. the United Kingdom, Application No. 48259/15, Decision of 23 June 2016.

112 Three of the applicants were scholars and professionals in the fields of archaeology and architecture, who had taken part in the excavation and restoration works at Hasankeyf; one was an attorney specialized in the protection of cultural heritage, and one a journalist.

113 Cf. Article 34 ECHR. See also B. Aykan, op. cit., p. 27.

114 Ahunbay et al. 2016 Decision, para. 86.

115 ECtHR, Research Division, Cultural Rights in the Case-law of the European Court of Human Rights, January 2011 (updated 17 January 2017), https://www.echr.coe.int/Documents/Research_report_cultural_rights_ ENG.pdf [accessed: 20.02.2019], para. 78.

116 Ibidem, para. 1

117 Kozacıoğlu v. Turkey, Application No. 2334/03, Judgment of 19 February 2009, para. 54.
} 
cle 8 ECHR). ${ }^{118}$ In yet another case, the Court recognized the need for a State Party to the Convention to ensure access to a book deemed to be part of the European literary heritage, regardless of that State Party's concern with its content. ${ }^{119}$

The Court's longer experience in addressing the challenge of environmental human rights adjudication (also not expressly mentioned in the ECHR) has allowed it to look to a variety of sources in search of signs of an evolution of moral values which would justify recourse to a dynamic (evolutive) interpretation of the ECHR. In Kyrtatos v. Greece, it even observed that "other international instruments and domestic legislation are more pertinent in dealing with this particular aspect" than the European Convention. ${ }^{120}$ This is directly related with the Court's conviction that the ECHR needs to maintain its effectiveness and relevance in a changing environment, and hence the need to treat it as a "living instrument". ${ }^{121}$ The principle of a dynamic, or evolutive interpretation of the Convention developed by the Court "facilitates the abandonment of outmoded interpretations of the Convention when significant, durable, and pan-European changes in the climate of public opinion have occurred". ${ }^{122}$ In trying to read the Convention in light of present-day conditions, the ECtHR has tended to regard collections of documents, some binding on the respective respondent State and some not, as evidence of overarching moral "common European standards", the validity of which does not depend on the state of obligations expressly assumed by the Member States. ${ }^{123}$ In this spirit, in Öneryıldız v. Turkey the Court referred to two environmental conventions which were not only not ratified by the respondent State, but have never entered into force at all. ${ }^{124}$ Similarly, in Taşkin v. Turkey the ECtHR interpreted Article 8 ECHR on the basis of the Aarhus Convention, ${ }^{125}$ neither ratified nor signed by Turkey, and Recommendation 1614 (2003) on the environment and human rights, adopted by the 2003 CoE Parliamentary Assembly. ${ }^{126}$ Finally, in Tătar v. Romania, the Court ex-

\footnotetext{
118 Sargsyan v. Azerbaijan, Application No. 40167/06, Judgment of 16 June 2015, para. 257.

119 Akdaş v. Turkey, Application No. 41056/04, Judgment of 16 February 2010, para. 30.

120 Kyrtatos v. Greece, Application No. 41666/98, Judgment of 22 May 2003, para. 52.

121 See e.g. Tyrer v. the United Kingdom, Application No. 5856/72, Judgment of 25 April 1978, para. 31 and Loizidou v. Turkey (Preliminary Objections), Application No. 15318/89, Judgment of 23 March 1995, paras $71-74$.

122 S. Greer, The European Convention on Human Rights. Achievements, Problems and Prospects, Cambridge University Press, Cambridge 2006, p. 214.

123 Cf. G. Letsas, Strasbourg's Interpretive Ethic: Lessons for the International Lawyer, "European Journal of International Law" 2010, Vol. 21(3), pp. 522-523.

124 In that case, the Court also relied on non-binding recommendations and resolutions of the Committee of Ministers and the Parliamentary Assembly as proof of common European standards in the field of environmental protection. See Öneryıldız v. Turkey, Application No. 48939/99, Judgment of 30 November 2004, para. 59.

125 Convention on Access to Information, Public Participation in Decision-making and Access to Justice in Environmental Matters, 25 June 1998, 2161 UNTS 447.
}

126 Taşkin v. Turkey, Application No. 46117/99, Judgment of 10 November 2004, para. 99. 


\section{GENERAL ARTICLES}

Berenika Drazewska

tensively quoted the (non-binding) 1972 Stockholm and 1992 Rio Principles and referred to other binding and non-binding instruments, including acts by European Union organs..$^{127}$

\section{Towards a recognition of a universal right to cultural heritage?}

In light of the Ahunbay et al. 2016 Decision, it certainly appeared as though the Court intended to look for evidence of commonly accepted standards pertaining to cultural heritage in a variety of international legal instruments and documents. According to the Court, the extensive legal framework applicable to the case included conventions and charters adopted by the CoE, namely the Valletta Convention (which in the Court's own words, "establishes a universal principle for the safeguarding and enhancement of heritage representative of all forms of cultural expression which have seen the light of day throughout the history of a given territory, independently of the political context which prevails in that territory at this or that moment" ${ }^{128}$ ); the Granada Convention; ${ }^{129}$ the Delphi Convention; ${ }^{130}$ the Strasbourg Charter ${ }^{131}$ the European Cultural Convention; the Faro Framework Convention; ${ }^{132}$ as well as CoE recommendations directed at Member States, including Recommendation R (89) 5 from 13 April $1989^{133}$ and Recommendation of the Parliamentary Assembly No. 880 from 8 October 1979.134 The applicable international law listed by the Court also included the World Heritage Convention; the Universal Declaration of Human Rights; ${ }^{135}$ ICESCR (with a reference to General Comment No. 21 of the CESCR pertaining to Article 15); and the Venice, ${ }^{136}$ Washington, ${ }^{137}$ and Lausanne ${ }^{138}$ Charters of ICOMOS, an international NGO active in the field of cultural protection and conservation. What

127 Tătar v. Romania, Application No. 67021/01, Judgment of 27 January 2009, para. 111.

128 Ahunbay et al. 2016 Decision, para. 69.

129 CoE Convention for the Protection of the Architectural Heritage of Europe, 3 October 1985, CETS 121.

130 CoE European Convention on Offences relating to Cultural Property, 23 June 1985, ETS 119.

131 CoE European Charter of the Architectural Heritage, October 1975.

132 CoE Framework Convention on the Value of Cultural Heritage for Society, 27 October 2005, CETS 199.

133 CoE Committee of Ministers, Recommendation No. R (89) 5 Concerning the Protection and Enhancement of the Archaeological Heritage in the Context of Town and Country Planning Operations, 13 April 1989 ("CoE Recommendation R (89) 5").

134 CoE Parliamentary Assembly, Recommendation 880 (1979): Conservation of the European Architectural Heritage, 8 October 1979 (“CoE Recommendation 880").

13510 December 1948, UNGA Res. $217 \mathrm{~A}(\mathrm{III})$, arts 22 and 27.

136 ICOMOS International Charter for the Conservation and Restoration of Monuments and Sites, 1964.

137 ICOMOS Charter for the Conservation of Historic Towns and Urban Areas, 1987.

138 ICOMOS Charter for the Protection and Management of the Archaeological Heritage, 1990. 
is remarkable about this collection is that many of these documents are not binding, while others would have been binding had Turkey ratified them. While Turkey is a party to the Valletta Convention, the Granada Convention, and the European Cultural Convention, as well as the World Heritage Convention and the ICESCR, the Decision also mentions the Delphi Convention, which never got sufficient ratifications to enter into force, ${ }^{139}$ and quotes liberally from the Faro Convention (which Turkey has never ratified), as well as from the CoE's explanatory report to that Convention. The CoE recommendations, the Strasbourg Charter as well as the Charters of ICOMOS are not international treaties and are not binding on Turkey, in the sense that it could not express its consent to be bound by them. The Court has further emphasized the relevance of these documents for the case by quoting them extensively in the Ahunbay et al. 2016 Decision. Judging from that Decision only, it certainly appeared as though the Court was minded to treat the referenced documents as manifestations of "common European standards" in protecting cultural heritage in its discussion over whether Turkey has violated its obligations under the ECHR. Based on that list, it seemed that the discussion would be informed by some or all of the following principles, concepts, and approaches: the principle of safeguarding (protecting) cultural heritage; ${ }^{140}$ access to heritage; ${ }^{141}$ the importance of heritage for the right to participate in cultural life; ${ }^{142}$ the fragile, non-renewable, and endangered character of heritage, ${ }^{143}$ participation of the public; ${ }^{144}$ expert consultation; ${ }^{145}$ integrated conservation; ${ }^{146}$ in situ preservation; ${ }^{147}$ consideration of cultural heritage as a factor in sustainable development; ${ }^{148}$ consideration of cultural heritage (and cultural heritage policies)

\footnotetext{
139 It has subsequently been replaced by the CoE Convention on Offences relating to Cultural Property, 19 May 2017, CETS 221, which currently awaits entry into force.

140 See the Faro Convention, art. 5; Valletta Convention, art. 1; Strasbourg Charter, Preamble and para. 10; European Cultural Convention, art. 1; CoE Recommendation 880, para. 15. See also the World Heritage Convention, art. 4 and CESCR, General Comment No. 21..., para. 50. The Washington Charter opens with an observation that many historic urban areas "are being threatened, physically degraded, damaged or even destroyed, by the impact of the urban development that follows industrialisation in societies everywhere" (see the Preamble).

141 Valletta Convention, art. 9(ii); European Cultural Convention, art. 5; Faro Convention, Preamble; as well as CESCR, General Comment No. 21..., paras 6 and 15.

142 Faro Convention, art. 1; Universal Declaration of Human Rights, art. 27; ICESCR, art. 15 (especially in light of CESCR, General Comment No. 21..., para. 50).

143 See the Lausanne Charter, art. 2; CoE Recommendation 880 (Preamble, para. 4).

144 See the Faro Convention, art. 12; Washington Charter, Principle 3; Lausanne Charter, art. 2.

145 See the Valletta Convention, art. 5; CoE Recommendation R (89) 5, para. III(iii).

146 See the Valletta Convention, art. 5; Granada Convention, art. 10; Strasbourg Charter, Preamble; Lausanne Charter, art. 2.

147 See the Valletta Convention, art. 5(iv) and the Lausanne Charter, art. 8.

148 See the Faro Convention, art. 5(e).
} 


\title{
GENERAL ARTICLES
}

\author{
Berenika Drazewska
}

in urban planning and management, ${ }^{149}$ including the duty to carry out impact assessment plans and mitigation strategies; ${ }^{150}$ and prevention of infractions against heritage..$^{151}$

As the above considerations have generally been missing in Turkey's handling of the Hasankeyf issue, it seemed likely that the Court would find that in the context of its human rights obligations Turkey has indeed fallen short of cultural heritage protection standards in planning and executing the llisu dam development project. However, contrary to what promised to be a progressive approach in the spirit of an evolutive interpretation of the Convention, in 2019 the Court declared that it has

so far not observed any "European consensus" or even a trend among Council of Europe Member States that might have called into question the scope of the rights in question or which would have permitted the inference from the provisions of the Convention of a universal individual right to the protection of a particular cultural heritage, as claimed in the present application. ${ }^{152}$

This indicates that the Court abandoned the progressive, evolutive perspective espoused in the Ahunbay et al. 2016 Decision for the sake of a strictly comparative approach. ${ }^{153}$ One might be tempted to question the logic of looking for evidence of such a consensus or trend solely within domestic legal orders, especially where an extensive international legal framework is readily available. Yet, the Court does not explain this change of trajectory, nor why it finally found the international and European standards (which may also be treated as a source of European consensus) listed in the Ahunbay et al. 2016 Decision unconvincing. This finding is all the more disappointing as the Court has recognized in its jurisprudence the need for parties to the ECHR to take measures to protect access to (European) common heritage (incidentally, in another case against Turkey). ${ }^{154}$ Thus, the Court affirmed the existence of "certain groups of cultural elements deemed to be 'common' to all people of

149 See the Valletta Convention, art. 5; Granada Convention, art. 20; Lausanne Charter, art. 2; Washington Charter, Principle 1; CoE Recommendation R (89) 5, para. III, and CoE Recommendation 880, para. 7, as well as World Heritage Convention, art. 5.

150 Faro Convention, art. 8; Lausanne Charter, arts 2 and 3.

151 See the Delphi Convention, art. 5.

152 Ahunbay et al. 2019 Decision, para. 25. All translations of texts available in French are the author's own.

153 For a discussion of the difference (and potential convergence) between the doctrine of evolutive interpretation and the "European consensus" argument as employed by the ECtHR, see generally K. Dzehtsiarou, European Consensus and the Evolutive Interpretation of the European Convention on Human Rights, "German Law Journal" 2011, Vol. 12(10), esp. pp. 1731-1734. The upshot is that while the two may overlap to a degree, "European consensus" seeks to follow the solution adopted by the majority of the members of the $\mathrm{CoE}$ and thus usually yields more predictable, if less daring, results in interpreting the ECHR compared to the evolutive interpretation.

154 Akdaş v. Turkey, para. 30. 
Europe". ${ }^{155}$ Although the applicants in Ahunbay et al. v. Turkey referred to Hasankeyf as not just the heritage of Europe, but of all mankind, ${ }^{156}$ the reluctance of the ECtHR to side with this view can probably be explained by its mistrust of actio popularis, which has attracted criticism from international law and human rights scholars. ${ }^{157}$

At the same time however, in the Ahunbay et al. 2019 Decision the Court seems to anticipate that this diagnosis might change in the future, as an evolution of moral attitudes is under way, stating that "the Court noted that the gradual increase in awareness of the values linked to conservation of the cultural heritage and access to it could be regarded as having created a certain international legal framework, and that the present case could consequently be falling within an evolving subject area [citations omitted]". ${ }^{158}$ Thus indirectly affirming the validity of the evolutive approach for future cases involving complaints of violation of cultural human rights, the Court further states that "in this context, in view of the international instruments and the common denominators of international law norms, even if not binding [citations omitted], the Court is prepared to consider that there is a community of European and international views on the need to protect the right of access to cultural heritage". ${ }^{159}$ The Ahunbay et al. v. Turkey case is the first in the Court's jurisprudence pertaining to cultural heritage to so exhaustively list (and quote from) the international (and European) cultural heritage treaty framework, much of which refers to the "common European" or even "universal" value of that heritage. ${ }^{160}$ That list surely goes a long way toward establishing a European consensus in this regard. In that sense, the Court might after all be sending an optimistic message concerning the possible future recognition of a universal right to cultural heritage in its jurisprudence. The methodology to interpret the ECHR accordingly is already in place.

In the meantime, the Ahunbay et al. 2019 Decision does not discourage individual petitions for violation of cultural rights per se. After all, the protection of cultural heritage remains an important component of the promotion and protection

\footnotetext{
155 A. Jakubowski, Common Cultural Heritage, the European Union, and International Law, in: A. Jakubowski, K. Hausler, F. Fiorentini (eds.), Cultural Heritage in the European Union - A Critical Inquiry into Law and Policy, Brill, Leiden, forthcoming, p. 47.

156 Cf. Ahunbay et al. 2016 Decision, para. 86, and Ahunbay et al. 2019 Decision, para. 16.

157 See F. Francioni, International Human Rights in an Environmental Horizon, "European Journal of International Law" 2010, Vol. 21(1), pp. 41-55 and R. Pavoni, Public Interest Environmental Litigation and the European Court of Human Rights: No Love at First Sight, in: F. Lenzerini, A.F. Vrdoljak (eds.), International Law for Common Goods: Normative Perspectives on Human Rights, Culture and Nature, Hart Publishing, Oxford 2014, pp. 331-359.

158 Ahunbay et al. 2019 Decision, para. 22.

159 Ibidem, para. 23.

160 See the Valletta Convention, art. 1; Strasbourg Charter, Preamble and para. 10; European Cultural Convention, arts 1 and 5. Cf. also the World Heritage Convention, Preamble, and Lausanne Charter, arts 3 and 9.
} 


\section{GENERAL ARTICLES}

Berenika Drazewska

of all human rights, including the full realization of cultural rights. ${ }^{161}$ However, as confirmed by the ECtHR in Ahunbay et al. v. Turkey, this protection generally targets situations and regulations concerning the right of minorities to freely enjoy their own culture as well as the right of indigenous peoples to preserve, control, and protect their cultural heritage. ${ }^{162}$ One may thus wonder if, hypothetically, this case would have had a better chance of prevailing at Strasbourg for the time being if the petition had been filed by a member (members) of the Kurdish minority residing in Hasankeyf, and therefore directly affected by its destruction.

\section{Conclusions}

The llisu dam case demonstrates the importance of following standards on the protection of cultural heritage, as well as environmental and human rights standards, in designing and executing large development projects. What's more, this case proves that stakeholders in such projects may find themselves under pressure to comply with more elevated standards on cultural heritage protection than those embodied in relevant national legislation and expressly assumed international commitments. In the llisu dam case, the World Bank safeguards and the recommendations of the WCD served as an important benchmark. As nowadays multilateral development agencies continue to adopt ever more sophisticated safeguarding policies on cultural heritage protection, ${ }^{163}$ those advanced policies may be increasingly treated as "best practices" as far as mitigation of the impact of development on cultural heritage is concerned, with standards on heritage protection in a whole variety of projects being directly "borrowed" from such policy documents.

Stakeholders who are prima facie "external" to the project, such as NGOs, the public, and ECAs may assume an important role in the process of implementation of social, environmental, and cultural heritage protection standards throughout a given project. In particular, the case discussed in this paper sets an important precedent as far as government-backed guarantees for development projects are concerned (the obligations of States to prevent human rights violations by companies supported by ECAs have since been affirmed by the United Nations, ${ }^{164}$

\footnotetext{
161 United Nations Human Rights Council Resolution No. 6/11, 28 September 2007, A/HRC/RES/6/11 (2007), para. 8 and General Comment No. 21..., para. 1.

162 See Ahunbay et al. 2019 Decision, paras 23 and 24.

163 See, e.g., World Bank, op. cit., pp. 75-88; European Investment Bank, Environmental and Social Handbook, Luxembourg 2018, ESS 5 (Cultural Heritage), pp. 39-43; European Bank for Reconstruction and Development, Environmental and Social Policy, London 2014, PR 8: Cultural Heritage, pp. 49-51; Inter-American Development Bank, Managing the Impacts of IDB Projects on Cultural Heritage, Washington 2015.

164 United Nations, Office of the High Commissioner for Human Rights, Guiding Principles on Business and Human Rights, New York - Geneva 2011, and CESCR, General Comment No. 24 on State Obligations under the International Covenant on Economic, Social and Cultural Rights in the Context of Business Activities, 10 August 2017, E/C.12/GC/24.
} 
the $\mathrm{OECD}, 165$ and the European Union, which established a review process whereby its Member States must submit reports on the activities of their ECAs to the European Commission). ECAs may want to include, and if need be make use of, an environmental default clause like the one inserted in the 2006 Agreement with Turkey in order to avoid association with projects falling short of such standards. Additionally, contractors may equally abandon such projects for fear of financial as well as reputational losses (as Balfour Beatty and Impregilo did in 2001, thus ending the first llisu consortium). ${ }^{166}$

Even though the ECtHR missed an opportunity to affirm the existence of a universal right to access cultural heritage in the context of the Turkish government's hydroelectric project, which gravely threatens Hasankeyf, the Ahunbay et al. v. Turkey case nonetheless has certain precedential value. In the case the Court has laid the cornerstone for future, potential enforcement of the right to access cultural heritage through human rights protection mechanisms. Based on its jurisprudence involving the evolutive interpretation of the ECHR, in the future the Court may be expected to hold States Parties to the Convention to uniformly high standards on cultural heritage protection, which might influence the interpretation of their human rights obligations under the ECHR. Although the Court might look for evidence of such "common standards" on cultural heritage protection in various instruments, both binding as well as non-binding on the respondent State, the final judgment of the Court will be legally binding on a State Party found to be in violation of the Convention. This approach must be seen as auspicious for future cases involving human rights complaints in connection with a State-sponsored destruction of cultural heritage in times of peace.

\section{References}

Ahunbay Z., Hasankeyf, a Site Threatened by the Ilisu Dam Project, in: M. Petzet, J. Ziesemer (eds.), Heritage at Risk: ICOMOS World Report 2006-2007 on Monuments and Sites in Danger, E. Reinhold-Verlag, Altenburg 2008.

Ahunbay Z., Observations Concerning the "Agreed Minutes of the Final Assessment Meeting (FAM) Regarding Ilısu Dam and Hydroelectric Power Plant Project", 5 August 2007, in: Berne Declaration, WEED, ECA-Watch, Summary of the Evaluation of the Terms of Reference and Their Implementation for the Ilisu Dam Project in Turkey Regarding Resettlement, Environmental Issues, Cultural Heritage and Riparian Countries, 11 September 2007, Annex 2, https://goo.gl/9r7zbs [accessed: 26.02.2019].

165 OECD, Recommendation of the Council on Common Approaches for Officially Supported Export Credits and Environmental and Social Due Diligence, 7 April 2016, TAD/ECG(2016)3.

166 To avoid precisely those risks, in 2011 the international mining company Rio Tinto adopted its own global guidelines on heritage protection, in cooperation with archaeologists. See E. Bradshaw et al., Why Cultural Heritage Matters: A Resource Guide for Integrating Cultural Heritage Management into Communities Work at Rio Tinto, Rio Tinto, Melbourne 2011. 


\title{
GENERAL ARTICLES
}

\author{
Berenika Drazewska
}

Ahunbay Z., Balkız Ö., Outstanding Universal Value of Hasankeyf and the Tigris Valley, Doğa Derneği 2009, https://goo.gl/qZ9tqX [accessed: 26.02.2019].

AKP No Different than ISIS, Destroying Ancient Sites in Hasankeyf, "ANF News", 14 August 2017, https://anfenglishmobile.com/kurdistan/akp-no-different-than-isis-destroyingancient-sites-in-hasankeyf-21543 [accessed: 11.02.2019].

Allason J., Hasankeyf, Turkey: Soon-to-be Sunken Treasure, "Financial Times", 8 March 2014.

Arango T., Turkish Dam Project Threatens to Submerge Thousands of Years of History, "New York Times", 1 September 2016, https://www.nytimes.com/2016/09/02/world/europe/ turkey-hasankeyf-ilisu-dam.html [accessed: 24.02.2019].

Ayboga E., European Court for Human Rights Rejects Appeal for Conserving Hasankeyf - An Act of Ignorance and Irresponsibility, 21 February 2019, http://www.hasankeyfgirisimi. net/?p=784 [accessed: 25.02 .2019 ].

Aykan B., Saving Hasankeyf: Limits and Possibilities of International Human Rights Law, "International Journal of Cultural Property" 2018, Vol. 25.

Berne Declaration, WEED, ECA-Watch, Summary of the Evaluation of the Terms of Reference and Their Implementation for the Ilisu Dam Project in Turkey Regarding Resettlement, Environmental Issues, Cultural Heritage and Riparian Countries, 11 September 2007, https:// goo.gl/9r7zbs [accessed: 26.02.2019].

Blake J., International Cultural Heritage Law, Oxford University Press, Oxford 2015.

Boisson de Chazournes L. et al., Note on Ilisu Dam Project/South-eastern Anatolia Project ("GAP"), 2 March 2007, in: Berne Declaration, WEED, ECA-Watch, Summary of the Evaluation of the Terms of Reference and Their Implementation for the Ilisu Dam Project in Turkey Regarding Resettlement, Environmental Issues, Cultural Heritage and Riparian Countries, 11 September 2007, Annex 3, https://goo.gl/9r7zbs [accessed: 26.02.2019].

Bolz D., Endangered Site: The City of Hasankeyf, Turkey, "Smithsonian Magazine", March 2009, https://www.smithsonianmag.com/travel/endangered-site-the-city-of-hasankeyfturkey-51947364/ [accessed: 6.02.2019].

Bosshard P., A Test Case of International Policy Coherence: A Case Study of the llisu Hydropower Project (Turkey), Memorandum to the UK Parliament submitted by the Berne Declaration, March 1999, https://www.publications.parliament.uk/pa/cm199900/cmselect/ cmtrdind/200/200ap07.htm [accessed: 6.02.2019].

Bradshaw E. et al., Why Cultural Heritage Matters: A Resource Guide for Integrating Cultural Heritage Management into Communities Work at Rio Tinto, Rio Tinto, Melbourne 2011.

Convention Concerning the Protection of the World Cultural and Natural Heritage, 16 November 1972, 1037 UNTS 151.

Convention for the Safeguarding of Intangible Cultural Heritage, 17 October 2003, 2368 UNTS 1.

Convention on Access to Information, Public Participation in Decision-making and Access to Justice in Environmental Matters, 25 June 1998, 2161 UNTS 447.

Convention on the Law of the Non-navigational Uses of International Watercourses, 21 May 1997, 36 ILM 700 (1997).

Council of Europe Committee of Ministers, Recommendation No. R (89) 5 Concerning the Protection and Enhancement of the Archaeological Heritage in the Context of Town and Country Planning Operations, 13 April 1989. 
Council of Europe Convention for the Protection of the Architectural Heritage of Europe, 3 October 1985, CETS 121.

Council of Europe Convention for the Protection of the Archaeological Heritage of Europe, 16 January 1992, CETS 143.

Council of Europe Convention on Offences relating to Cultural Property, 19 May 2017, CETS 221.

Council of Europe European Charter of the Architectural Heritage, October 1975.

Council of Europe European Convention on Offences relating to Cultural Property, 23 June 1985, ETS 119.

Council of Europe European Cultural Convention, 19 December 1954, ETS 18.

Council of Europe Framework Convention on the Value of Cultural Heritage for Society, 27 October 2005, CETS 199.

Council of Europe Parliamentary Assembly, Recommendation 880 (1979): Conservation of the European Architectural Heritage, 8 October 1979.

Council of Europe Parliamentary Assembly, Committee on Culture, Science and Education, Cultural Aspects of the Ilisu Dam Project, Turkey, information report, 18 December 2001.

Council of Europe, Sub-Committee on Cultural Heritage, Ilisu Hydropower Project, Turkey: Report Prepared on Behalf of Euler Hermes (Germany), OeKB (Austria) and SERV (Switzerland), first site visit, Dec. 2-11, 2007, 4 February 2008, http://m-h-s.org/ilisu/upload/ PDF/Analysen/Bericht_Kulturelles_Erbe.pdf [accessed: 19.02.2019].

Council of Europe, Sub-Committee on Cultural Heritage, Ilisu Hydropower Project, Turkey: Report Prepared on Behalf of Euler Hermes (Germany), OeKB (Austria) and SERV (Switzerland), second site visit, Aug. 10-21, 2008, 20 October 2008, http://m-h-s.org/ilisu/upload/PDF/Analysen/Bericht_KulturellesErbe_Okt2008.pdf [accessed: 19.02.2019].

CounterCurrent - GegenStrömung et al., Dam Construction in Turkey and Its Impact on Economic, Cultural and Social Rights. Parallel Report in Response to the Initial Report by the Republic of Turkey on the Implementation of the International Covenant on Economic, Social and Cultural Rights, 14 March 2011, https://goo.gl/qYWJwy [accessed: 6.03.2019].

DekaBank, Bank Austria, Société Générale, Press Release of 7 July 2009, https://goo.gl/XSsrce [accessed: 6.03.2019].

Doğa Derneği, Hasankeyf Survey Report, 2012, https://www.dogadernegi.org/wp-content/uploads/2015/10/HASANKEYF-SURVEY-REPORT-Summary.pdf [accessed: 13.02.2019].

Dzehtsiarou K., European Consensus and the Evolutive Interpretation of the European Convention on Human Rights, "German Law Journal" 2011, Vol. 12(10).

Eberlein C. et al., The Ilisu Dam in Turkey and the Role of Export Credit Agencies and NGO Networks, "Water Alternatives" 2010, Vol. 3(2).

Elliott S., Damming Ava Mezin. Challenges to Safeguarding Minority Intangible Cultural Heritage in Turkey, in: M.L. Stefano, P. Davis (eds.), The Routledge Companion to Intangible Cultural Heritage, Routledge, London 2017.

Europa Nostra's Board Gives Statement on the Endangered Heritage Site of Hasankeyf, Turkey, Europa Nostra, 29 June 2017, http://www.europanostra.org/europa-nostras-board-gives-statement-endangered-heritage-site-hasankeyf-turkey [accessed: 6.03.2019]. 


\title{
GENERAL ARTICLES
}

\author{
Berenika Drazewska
}

European Bank for Reconstruction and Development, Environmental and Social Policy, London 2014.

European Convention on Human Rights, 4 November 1950, 213 UNTS 221.

European Court of Human Rights, Ahunbay and Others v. Turkey, Application No. 6080/06, Decision of 29 January 2019.

European Court of Human Rights, Ahunbay and Others v. Turkey, Austria and Germany, Application No. 6080/06, Decision of 21 June 2016.

European Court of Human Rights, Akdaş v. Turkey, Application No. 41056/04, Judgment of 16 February 2010.

European Court of Human Rights, Kozacıoğlu v. Turkey, Application No. 2334/03, Judgment of 19 February 2009.

European Court of Human Rights, Kyrtatos v. Greece, Application No. 41666/98, Judgment of 22 May 2003.

European Court of Human Rights, L'Erablière A.S.B.L. v. Belgium, Application No. 49230/07, Judgment of 24 February 2009.

European Court of Human Rights, Loizidou v. Turkey (Preliminary Objections), Application No. 15318/89, Judgment of 23 March 1995.

European Court of Human Rights, Öneryıldız v. Turkey, Application No. 48939/99, Judgment of 30 November 2004.

European Court of Human Rights, Practical Guide on Admissibility Criteria (updated 31 December 2018), https://www.echr.coe.int/Documents/Admissibility_guide_ENG.pdf [accessed: 26.02.2019].

European Court of Human Rights, Rules of Court, 1 August 2018, https://www.echr.coe.int/ Documents/Rules_Court_ENG.pdf [accessed: 6.03.2019].

European Court of Human Rights, Sargsyan v. Azerbaijan, Application No. 40167/06, Judgment of 16 June 2015.

European Court of Human Rights, Syllogos Ton Athinaion v. the United Kingdom, Application No. 48259/15, Decision of 23 June 2016.

European Court of Human Rights, Taşkin v. Turkey, Application No. 46117/99, Judgment of 10 November 2004.

European Court of Human Rights, Tătar v. Romania, Application No. 67021/01, Judgment of 27 January 2009.

European Court of Human Rights, Tyrer v. the United Kingdom, Application No. 5856/72, Judgment of 25 April 1978.

European Court of Human Rights, Research Division, Cultural Rights in the Case-law of the European Court of Human Rights, January 2011 (updated 17 January 2017), https:// www.echr.coe.int/Documents/Research_report_cultural_rights_ENG.pdf [accessed: 20.02.2019].

European Investment Bank, Environmental and Social Handbook, Luxembourg 2018.

European Parliament, Resolution of 10 February 2010 on Turkey's progress report 2009, 10 February 2010, P7_TA(2010)0025.

Francioni F., International Human Rights in an Environmental Horizon, "European Journal of International Law" 2010, Vol. 21(1).

Garen M., Carleton M.-H., Deep Divide, "Financial Times”, 21 March 2008. 
Greer S., The European Convention on Human Rights. Achievements, Problems and Prospects, Cambridge University Press, Cambridge 2006.

Harris L., Turkey: Government Looks to China as Europe Suspends Funding for Ilisu Dam, "Art Newspaper", 18 September 2009.

Harte J., New Dam in Turkey Threatens to Flood Ancient City and Archaeological Sites, "National Geographic", 21 February 2014, https://news.nationalgeographic.com/ news/2014/02/140221-tigris-river-dam-hasankeyf-turkey-iraq-water/ [accessed: 25.02.2019].

Hildyard N. et al., The Ilisu Dam, the World Commission on Dams and Export Credit Reform: The Final Report of a Fact-finding Mission to the Ilisu Dam Region, Kurdish Human Rights Project, 2000, http://www.thecornerhouse.org.uk/resource/ilisu-dam-world-commission-dams-and-export-credit-reform [accessed: 24.02.2019].

Höhler G., Gaserow V., Berlin legt Ilisu-Staudamm trocken, "Frankfurter Rundschau", 7 July 2009.

ICOMOS Charter for the Conservation of Historic Towns and Urban Areas, 1987.

ICOMOS Charter for the Protection and Management of the Archaeological Heritage, 1990.

ICOMOS International Charter for the Conservation and Restoration of Monuments and Sites, 1964.

Initiative to Keep Hasankeyf Alive, Report on the Current Status of the llisu Hydroelectric Power Plant Project and Hasankeyf, 11 September 2017, http://www.hasankeyfgirisimi. net/?page_id=6 [accessed: 18.02 .2019$]$.

Initiative to Keep Hasankeyf Alive, GegenStrömung - CounterCurrent, Proposed Questions to the Government of the Republic of Turkey Regarding Economic, Social and Cultural Rights of the Population Affected by Large Dams, Notably the Ilisu Hydropower Plant, 29 April 2010, https://goo.gl/z8ookk [accessed: 6.03.2019].

Insurers Halt Work on Turkish Dam, "BBC News", 24 December 2008, http://news.bbc. co.uk/2/hi/europe/7798857.stm [accessed: 20.02.2019].

Inter-American Development Bank, Managing the Impacts of IDB Projects on Cultural Heritage, Washington 2015.

Jakubowski A., Common Cultural Heritage, the European Union, and International Law, in: A. Jakubowski, K. Hausler, F. Fiorentini (eds.), Cultural Heritage in the European Union - A Critical Inquiry into Law and Policy, Brill, Leiden, forthcoming.

Keine Garantien für umstrittenen Ilisu-Damm, “Neue Zürcher Zeitung”, 7 July 2009.

Law No. 2863 of 21 July 1983 on Conservation of Cultural and Natural Property (Turkey).

Letsas G., Strasbourg's Interpretive Ethic: Lessons for the International Lawyer, "European Journal of International Law" 2010, Vol. 21(3).

Lindsey D., The Turkish Dam That "Would Never Have Been Permitted" in Germany, "Spiegel Online", 8 July 2009, http://www.spiegel.de/international/world/the-world-from-berlinthe-turkish-dam-that-wouldnever-have-been-permitted-in-germany-a-635054.html [accessed: 6.03.2019].

Monbiot G., Depraved Debt Collectors: A Shadowy Agency Underwrites Scores of Macabre Schemes, "The Guardian" (international edition), 14 October 1999.

OECD, Recommendation of the Council on Common Approaches for Officially Supported Export Credits and Environmental and Social Due Diligence, 7 April 2016, TAD/ECG(2016)3. 


\title{
GENERAL ARTICLES
}

\author{
Berenika Drazewska
}

Pavoni R., Public Interest Environmental Litigation and the European Court of Human Rights: No Love at First Sight, in: F. Lenzerini, A.F. Vrdoljak (eds.), International Law for Common Goods: Normative Perspectives on Human Rights, Culture and Nature, Hart Publishing, Oxford 2014.

Ronayne M., The Cultural and Environmental Impact of Large Dams in Southeast Turkey, National University of Ireland, Galway and Kurdish Human Rights Project, London 2005, https://aran.library.nuigalway.ie/handle/10379/1546 [accessed: 25.02.2019].

Ronayne M., Ascherson N., Opposition to Turkey's Ilisu Dam Rises Again, "China Dialogue", 1 September 2006, https://www.chinadialogue.net/article/show/single/en/336-Opposition-to-Turkey-s-Ilisu-Dam-rises-again [accessed: 26.02.2019].

Seufert G., Das Böse kommt von draußen, "Zeit Online", 10 July 2009.

Shepperson M., How Archaeologists Discovered an Ancient Assyrian City - And Lost It Again, "The Guardian" (international edition), 7 February 2018.

Shoup D., Can Archaeology Build a Dam? Sites and Politics in Turkey's Southeast Anatolia Project, "Journal of Mediterranean Archaeology" 2006, Vol. 19(2).

Smith H.L., Turkish Monuments Wheeled Out of Town Before Flood 'Washes History Away', "The Times" (UK), 8 August 2018, https://www.thetimes.co.uk/article/monumentswheeled-out-of-town-before-flood-washes-history-away-tn7cx0xzn [accessed: 26.02.2019].

Swiss Bank Quits Turkish Dam Project, "BBC News", 27 February 2002, http://news.bbc. co.uk/2/hi/europe/1844465.stm [accessed: 20.02.2019].

United Nations Committee on Economic, Social and Cultural Rights, Consideration of Reports Submitted by States Parties under Articles 16 and 17 of the Covenant: Concluding Observations of the Committee on Economic, Social and Cultural Rights: Turkey, 12 July 2011, E/C.12/TUR/CO/1.

United Nations Committee on Economic, Social and Cultural Rights, General Comment No. 21, Right of Everyone to Take Part in Cultural Life (art. 15, para. 1a of the Covenant on Economic, Social and Cultural Rights), 21 December 2009, E/C.12/GC/21.

United Nations Committee on Economic, Social and Cultural Rights, General Comment No. 24 on State Obligations under the International Covenant on Economic, Social and Cultural Rights in the Context of Business Activities, 10 August 2017, E/C.12/GC/24.

United Nations Human Rights Council Resolution No. 6/11, 28 September 2007, A/HRC/ RES/6/11 (2007).

United Nations, Office of the High Commissioner for Human Rights, Guiding Principles on Business and Human Rights, New York - Geneva 2011.

Universal Declaration of Human Rights, 10 December 1948, UNGA Res. 217 A(III).

Warner J., The Struggle over Turkey's Ilısu Dam: Domestic and International Security Linkages, "International Environmental Agreements" 2012, Vol. 12.

World Bank, Environmental and Social Framework, Washington 2017.

World Commission on Dams, Dams and Development: A New Framework For Decision-Making. The Report of the World Commission On Dams, Earthscan, London - Sterling, November 2000.

World Heritage Committee, Operational Guidelines for the Implementation of the World Heritage Convention (2017).

Young P., Hasankeyf: A City in Peril, "History Today" 2000, Vol. 50(11). 